\title{
Cardiac cGMP/cGMP-dependent protein kinase I signalling requires cysteine-rich LIM-only protein 4 (CRP4) to oppose angiotensin II induced hypertrophy and fibrosis
}

\author{
Julia Straubinger ${ }^{*}$, Peter Ruth, Robert Lukowski \\ From 6th International Conference on cGMP: Generators, Effectors and Therapeutic Implications \\ Erfurt, Germany. 28-30 June 2013
}

\section{Background}

Cardiac hypertrophy is an adaptive response of the heart to many cardio-vascular disorders including hypertension, infarction and defects of the valves. Elevated levels of cardiac cyclic guanosine-3', 5'-monophosphate (cGMP) activate cGMP-dependent protein kinase I (cGKI), which reportedly exhibited either anti-fibrotic and/or antihypertrophic effects or did not change the cardiac remodeling responses [1-5]. Based on these findings, we and others suggested that the ability of natriuretic peptides (NP) to oppose detrimental changes via cGMP/cGKI might strongly depend on the growth-promoting neurohormonal signals and stresses. Aiming to dissect the molecular details underlying cardiac cGMP signaling, we investigated the cysteine-rich LIM-only protein 4 (CRP4) as a novel target of cardio-vascular cGMP in vivo. CRP4 is phosphorylated at Ser-104 by cGMP/cGKI [6-8] and a highly related homologue of the muscle LIM protein CRP3/MLP, which has been linked to dilated and hypertrophic cardiomyopathies in mice and humans $[9,10]$.

\section{Materials and methods}

A patho-/physiological growth adaption of the heart muscle was induced either by an increase in afterload upon chronic angiotensin II (AngII) infusions $(2 \mathrm{mg} / \mathrm{kg} / \mathrm{d})$ or healthy exercise training using a duration-controlled swimming protocol in CRP4 knockout (KO), wild type (WT) and heterozygous (HET) littermates. The extent of the cardiac growth response was defined by referring changes in heart weight $(\mathrm{HW})$ to body weight $(\mathrm{HW} / \mathrm{BW})$

\footnotetext{
* Correspondence: julia.straubinger@uni-tuebingen.de

Pharmakologie, Toxikologie und Klinische Pharmazie, Institut für Pharmazie, Universität Tübingen, Tübingen, Germany
}

and tibia length (HW/TL). Hypertrophic marker genes, putative effects of AngII on components of the NP/ cGMP/cGKI pathway and the expression pattern of other members of the CRP protein family were analyzed in total mRNA and protein preparations isolated from healthy and hypertrophic ventricles. These experiments were corroborated by the localization of CRP4 in the myocardium and Sirius Red staining as a quantitative measure of fibrosis.

\section{Results}

CRP4 mRNA and protein levels were significantly reduced in HET hearts and absent from $\mathrm{KO}$ muscles. $\mathrm{HW} / \mathrm{BW}$ and HW/TL ratios of all three genotypes did not differ at baseline, however, cardiomyocyte size and heart ratios were elevated in CRP4 HET and KO animals in response to the AngII infusions. Interstitial fibrosis was significantly stimulated by AngII in CRP4deficient and HET hearts, whereas the production of anti-fibrotic factors such as BNP was diminished. Importantly, no differences between the genotypes in cardiac mass or the amount of fibrosis were detected upon swimming exercises.

\section{Conclusion}

The increased susceptibility of CRP4-deficient hearts to chronic AngII exposure indicates that beneficial effects of cGMP/cGKI to oppose Gaq-mediated signaling require cardiac CRP4.

Published: 29 August 2013 


\section{References}

1. Takimoto E, Champion HC, Li M, Belardi D, Ren S, Rodriguez ER, Bedja D, Gabrielson KL, Wang Y, Kass DA: Chronic inhibition of cyclic GMP phosphodiesterase $5 \mathrm{~A}$ prevents and reverses cardiac hypertrophy. Nature Med 2005, 1:214-222.

2. Lukowski R, Rybalkin SD, Loga F, Leiss V, Beavo JA, Hofmann F: Cardiac hypertrophy is not amplified by deletion of cGMP-dependent protein kinase I in cardiomyocytes. Proc Natl Acad Sci USA 2010, 107:5646-565.

3. Frantz S, Klaiber M, Baba HA, Oberwinkler H, Volker K, Gabetaner B, Bayer B, Abebetaer M, Schuh K, Feil R, Hofmann F, Kuhn M: Stress-dependent dilated cardiomyopathy in mice with cardiomyocyte-restricted inactivation of cyclic GMP- dependent protein kinase I. Eur Heart J 2013, 34:1233-1244.

4. Klaiber M, Dankworth B, Kruse M, Hartmann M, Nikolaev VO, Yang RB, Volker K, Gassner B, Oberwinkler H, Feil R, Freichel M, Groschner K, Skryabin BV, Frantz S, Birnbaumer L, Pongs O, Kuhn M: A cardiac pathway of cyclic GMP-independent signaling of guanylyl cyclase $A$, the receptor for atrial natriuretic peptide. Proc Natl Acad Sci USA 2011، 108:18500-18505.

5. Blanton RM, Takimoto E, Lane AM, Aronovitz M, Piotrowski R, Karas RH, Kass DA, Mendelsohn ME: Protein kinase $g$ ialpha inhibits pressure overload-induced cardiac remodeling and is required for the cardioprotective effect of sildenafil in vivo. J Amer Heart Assoc 2012, 1 e003731.

6. Huber A, Neuhuber WL, Klugbauer N, Ruth P, Allescher HD: Cysteine-rich protein 2, a novel substrate for CGMP kinase I in enteric neurons and intestinal smooth muscle. J Biol Chem 2000, 275:5504-5511.

7. Schmidtko A, Gao W, Sausbier M, Rauhmeier I, Sausbier U, Niederberger E, Scholich K, Huber A, Neuhuber W, Allescher HD, Hofmann F, Tegeder I, Ruth P, Geisslinger G: Cysteine-rich protein 2, a novel downstream effector of CGMP/CGMP-dependent protein kinase I-mediated persistent inflammatory pain. J Neurosci 2008, 28:1320-1330.

8. Zhang T, Zhuang S, Casteel DE, Looney DJ, Boss GR, Pilz RB: A cysteine-rich LIM- only protein mediates regulation of smooth muscle-specific gene expression by CGMP-dependent protein kinase. J Biol Chem 2007, 282:33367-33380.

9. Arber S, Hunter JJ, Ross J Jr, Hongo M, Sansig G, Borg J, Perriard JC, Chien KR, Caroni P: MLP-deficient mice exhibit a disruption of cardiac cytoarchitectural organization, dilated cardiomyopathy, and heart failure. Cell 1997, 88:393-403.

10. Geier C, Perrot A, Ozcelik C, Binner P, Counsell D, Hoffmann K, Pilz B, Martiniak $Y$, Gehmlich $K$, van der Ven PF, Furst DO, Vornwald A, von Hodenberg E, Nurnberg P, Scheffold T, Dietz R, Osterziel KJ: Mutations in the human muscle LIM protein gene in families with hypertrophic cardiomyopathy. Circulation 2003, 107:1390-1395.

doi:10.1186/2050-6511-14-S1-P68

Cite this article as: Straubinger et al.: Cardiac cGMP/cGMP-dependent protein kinase I signalling requires cysteine-rich LIM-only protein 4 (CRP4) to oppose angiotensin II induced hypertrophy and fibrosis. BMC Pharmacology and Toxicology 2013 14(Suppl 1):P68.

\section{Submit your next manuscript to BioMed Central and take full advantage of:}

- Convenient online submission

- Thorough peer review

- No space constraints or color figure charges

- Immediate publication on acceptance

- Inclusion in PubMed, CAS, Scopus and Google Scholar

- Research which is freely available for redistribution

Submit your manuscript at www.biomedcentral.com/submit
Biomed Central 